\section{Questions that Count in Historical Archaeology}

\section{Plenary Session, 1987 Meeting of the Society for Historical Archaeology Conference on Historical and Underwater Archaeology Savannah, Georgia}

\author{
Edited by Nicholas HoNeRKamp \\ Department of Sociology and ANTHROPOLOGY \\ University of TenNessee at Chattanooga \\ Chattanooga, Tennessee 37403
}

\section{Preface}

One of the most memorable sessions I ever attended at the annual meetings of the Society for Historical Archaeology was held in 1975 in Charleston, South Carolina. At that meeting Leland Ferguson put together a thematic symposium entitled "The Importance of Material Things," and he invited the best and brightest inside and outside of historical archaeology to contribute; James Deetz, Lewis Binford, Mark Leone, Henry Glassie, William Rathje, Charles Fitting (the discussant), and Ferguson all participated. The session was unusual in its focus on method and theory, the ideas presented were startling in their originality, and the presentations were all forceful and eloquent (and, in the case of Deetz, hilarious-no mean feat). As a graduate student I found this event to be immensely exciting, and later, immensely useful in developing my own theoretical perspective. Of course, any theory session is bound to be controversial, and a number of people disagreed with some of the views presented. I particularly remember the look of shocked disbelief on the face of someone (a historian?) sitting next to me when Glassie, alluding to the unusual conditions that generate and preserve the written record, described documentary research as "a stringing together of nuts." In 1977 the papers were published by the Society under the title of
Historical Archaeology and the Importance of Material Things (Special Publications, Number 2), required reading for anyone who strings together nuts or is otherwise involved in historical archaeology.

As SHA program chair for the 1987 version of what is now called the Society for Historical Archaeology Conference on Historical and Underwater Archaeology, held in Savannah, I had the opportunity to organize a plenary session on anything I wanted. With the Charleston symposium as an inspiration I chose a theoretical focus on the "Questions That Count In Historical Archaeology," and then asked six of the most interesting and productive people I could think of to participate. Charles Cleland, Kathleen Deagan, Mark Leone, Stephen Mrozowski, Robert Schuyler, and Stanley South all enthusiastically agreed to contribute papers. At South's suggestion, the structure of the session was for each participant to present a relatively brief " position statement," followed by a roundtable discussion moderated by Cleland. (The spirited dialogue that emerged from the ensuing discussion was tragically cut short due to time constraints, but illustrated once more the value of a format that is becoming rare at professional archaeology meetings.)

My concern with method and theory stems from a number of factors. First was the personal feeling of theoretical angst I have experienced over the last few years, one that was shared in various degrees by all the participants. With a few notable exceptions, the direction that historical archaeology has taken over the last two decades has been distinctly atheoretical, and as a consequence we seem to have entered a "normal science" phase, by which I mean that a great deal of research has become highly routinized. Methodologies developed a decade or more ago are routinely applied, reports are written, papers and publications generated, etc., without much thought as to whether the routine is worth the effort. As evidenced by most of the published work in our discipline, someone seems to have declared a moratorium on thinking about and discussing the reasons that underlie historic sites research. We ignore theory at our peril, however, because it is very easy to become scien- 
tifically and/or humanistically superfluous if we do not continually redefine what is important to know and why it is important. If as archaeologists we can identify questions that matter and then explain why they matter, a number of things then begin to fall into place. For instance, field methodologies and analysis routines become driven by solid research designs instead of existing in a theoretical vacuum and being applied in mechanistic fashion; in the cultural resource management context, the "significance" concept becomes better defined and less slippery in its application; and interpretations for our ultimate sponsors in the public and private sectors about what archaeologists do with their money rise above the empty "greater appreciation of the past" statements that usually characterize such efforts. My ultimate goal in organizing the session was not to get all historical archaeologists to agree on a particular theoretical approachclearly impossible, and undesireable besides - but rather to think as well as do. The papers that follow, with minor revisions, are as they were presented at the plenary session, and I believe they succeed very well in achieving this goal. Finally, I hope the plenary session is useful in countering an unfortunate trend in the last few years at the annual meetings of dispensing with the single-session plenary or keynote format. If nothing else, the session at Savannah can be seen as a rite of solidarity that brought together physically in one place, however briefly, the members of a diverse archaeological community. As anthropologists we are well aware of the necessity for a successful society to engage in rituals that find meaning in promoting identity, solidarity, and unity of purpose among its members. The Society for Historical Archaeology is not exempt from this ethnographic fact of life.

To conclude this preface, I need to extend my thanks to each of the authors for their contributions to the Savannah plenary ritual, and for sharing with us their thoughts on the questions that count in historical archaeology. I am especially indebted to Kathleen Deagan for her encouragement and suggestions during the session's early planning stages. I also wish to acknowledge the support and efforts of Larry Babits, the general conference chair, and Kathryn Levitt, conference coordinator, who made the 20th annual meeting and this session possible. Finally, I thank Ronald Michael for his initiative and energy in bringing about the publication of the following papers.

Nicholas HoNERKAMP 